ISSN $1410-9840$

\title{
ANALISIS PRIORITAS PENANGANAN PERBAIKAN PRASARANA SDA WILAYAH SUNGAI BODRI KUTO DENGAN AHP EXPERT CHOICE
}

\author{
Bambang Sudarmanto \\ Dosen Tetap Jurusan Teknik Sipil Universitas Semarang \\ E-mail: bambangsudarmanto68@gmail.com
}

\section{RINGKASAN}

\begin{abstract}
Wilayah Sungai Bodri Kuto yang merupakan kewenangan Dinas PSDA Provinsi Jawa Tengah menghadapi beberapa masalah yang kompleks dan saling terkait. Permasalahan tersebut antara lain terjadinya erosi, banjir, kekeringan, masih belum adanya keterpaduan antar sektor, antar instansi dan kesadaran msyarakat yang rendah tentang pelestarian manfaat sumber daya alam. Permasalahan-permasalahan yang kompleks tersebut dijadikan pertimbangan utama dalam menata dan menyusun prioritas program dengan cara mensimulasikan atau memformulasikan permasalahan tersebut dalam bentuk parameter-parameter yang akan diolah menggunakan software AHP Expert Choice. Dengan menggunakan metode AHP Expert Choice, parameter-parameter yang mempengaruhi terhadap alasan penyusunan prioritas penanganan prasarana SDA WS Bodri Kuto disusun dalam tingkatan (hirarki) yang terbagi dalam komponen elemen-elemennya. Kemudian masing-masing parameter tersebut diberi bobot yang tentunya membutuhkan kesepakatan dengan para pihak yang terkait dan terlibat dalam pengelolaan SDA WS Bodri Kuto.

Hasil studi Analisis Prioritas Penanganan Perbaikan Prasarana SDA WS Bodri Kuto dengan AHP Expert Choice menghasilkan rangking prioritas DAS yang perlu ditangani sebagai berikut : DAS Kuto, DAS Damar, DAS Bulanan, DAS Blukar, DAS Bodri, DAS Buntu, DAS Kendal, DAS Blorong, DAS Waridin, DAS Aji, dan DAS Plumbon.

Kata Kunci : Daerah Aliran Sungai (DAS), AHP Expert Choice.
\end{abstract}

\section{PENDAHULUAN}

Wilayah Sungai Bodri Kuto yang merupakan kewenangan Dinas PSDA Provinsi Jawa Tengah menghadapi beberapa masalah yaitu : Banjir, kekeringan dan tanah longsor; Masih rendahnya kesadaran masyarakat dalam pemeliharaan lingkungan dan lemahnya penegak hokum terhadap pembalakan liar; Belum adanya instansi yng berfungsi sebagai wadah koordinasi; Peran serta masyarakat dalam perencanaan pelaksanaan dan pengawasan belum optimal; Belum ada penjelasan mengenai pembagian anggaran rencana untuk drainase dan lingkungan hidup; Masih lemahnya kelembagaan pengelolaan irigasi di tingkat usaha tani; Kekurangan air baku tiap musim kemarau; Belum adanya pengelolaan sarana prasarana SDA; Terbatasnya dana yang tersedia untuk OP tiap tahun; Masih kurangnya kemampuan dan pemberdayaan peran serta masyarakat dan swasta; Masih kurangnya kinerja pelaksana teknis pengelola SDA; Kurangnya informasi mengenai SDA; Upaya pengusahaan SDA yang urang optimal; Penggunaan air yang tidak sesuai kebutuhan; Alih fungsi lahan; Pengunaan air yang tidak berlebihan; Kerusakan sarana dan prasarana sanitasi; Kerusakan sumber air; Lokasi kritis; serta Pengambilan gol-gol C di sungai yang tidak terkendali.

Permasalahan-permasalahan yang kompleks seperti diatas dijadikan pertimbangan utama dalam menata dan 
menyusun prioritas program dengan cara mensimulasikan atau memformulasikan permasalahan tersebut dalam bentuk parameter-parameter yang akan diolah menggunakan software AHP Expert Choice. Dengan menggunakan metode AHP Expert Choice, parameter-parameter yang mempengaruhi terhadap alasan penyusunan prioritas penanganan prasarana SDA WS Bodri Kuto disusun dalam tingkatan (hirarki) yang terbagi dalam komponen elemen-elemennya. Kemudian masing-masing parameter tersebut diberi bobot yang tentunya membutuhkan kesepakatan dengan para pihak yang terkait dan terlibat dalam pengelolaan SDA WS Bodri Kuto.

\section{METODOLOGI}

Dasar dan acuan penilaian kinerja DAS telah diatur oleh pemerintah melalui Kepmen Kehutanan No. 52/Kpts-II/2001. Rangkuman kriteria dan indikator kinerja DAS dapat ditampilkan dalam bentuk matriks berikut :

Tabel 2.1.

Kriteria dan Indikator Kinerja DAS

\begin{tabular}{|c|c|c|c|c|}
\hline KRITERIA & INDIKATOR & PARAMETER & STANDAR EVALUASI & KETERANGAN \\
\hline \multirow[t]{4}{*}{$\begin{array}{l}\text { A. Penggunaan } \\
\text { Lahan }\end{array}$} & 1. Penutupan oleh vegetasi & $\mathrm{IPL}=$\begin{tabular}{crr}
$\mathrm{L}$ & $\mathrm{V}$ & $\mathrm{P}$ \\
\hdashline Luas DAS & &
\end{tabular} & 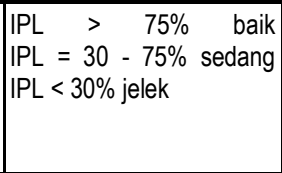 & $\begin{array}{l}\text { IPL = indek penutupan lahan } \\
\text { LVP = luas lahan bervegetasi } \\
\text { permanen } \\
\text { Informasi dari peta penutupan } \\
\text { lahan atau land use }\end{array}$ \\
\hline & $\begin{array}{l}\text { 2. Kesesuaian Penggunaan } \\
\text { Lahan (KPL) }\end{array}$ & 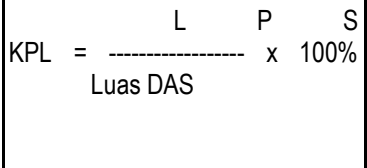 & 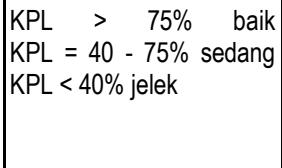 & $\begin{array}{l}\text { LPS = luas penggunaan lahan } \\
\text { yang sesuai } \\
\text { Rujukan kesesuaian penggunaan } \\
\text { lahan adalah RTRW/K dan atau } \\
\text { pola RLKT }\end{array}$ \\
\hline & 3. Erosi, Indek Erosi (IE) & 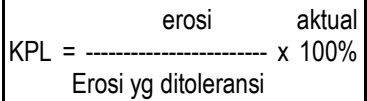 & $\begin{array}{l}\mathrm{IE} \\
\mathrm{IE}>1 \text { jelek }\end{array}$ & $\begin{array}{l}\text { Perhitungan erosi merujuk } \\
\text { pedoman RTL-RLKT } 1998\end{array}$ \\
\hline & 4. Pengelolaan lahan & $\begin{array}{l}\text { Pola tanam }(\mathrm{C}) \text { dan tindakan } \\
\text { konservasi }(\mathrm{P})\end{array}$ & $\begin{array}{l}C \times P \leq 0,10 \text { baik } \\
C \times P=0,10-0,50 \text { sedang } \\
C \times P \geq 0,50 \text { jelek }\end{array}$ & $\begin{array}{l}\text { Perhitungan nilai C \& P merujuk } \\
\text { pedoman RTL-RLKT tahun } 1998\end{array}$ \\
\hline \multirow[t]{4}{*}{ B. Tata Air } & 1. Debit air sungai & 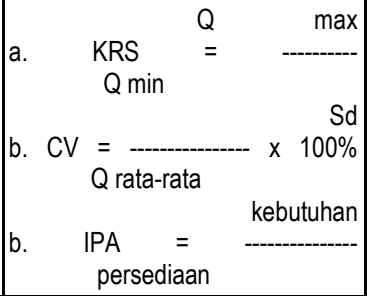 & 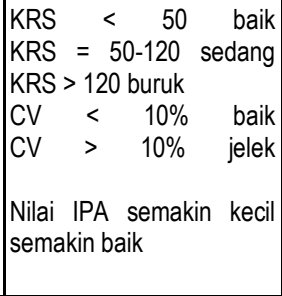 & $\begin{array}{|llll|}\text { Data } & \text { SPAS } & \text { PU/BRLKT/HPH } \\
Q & = & \text { debit } & \text { sungai } \\
& & & \\
\text { CV } & = & \text { coefisien } & \text { varian } \\
\text { Sd }= & \text { standar } & \text { deviasi } \\
\text { Data SPAS } & & \\
\text { IPA = Indek Penggunaan Air }\end{array}$ \\
\hline & 2. Kandugan sedimen & Kadar lumpur dalam air & \begin{tabular}{|lr} 
Semakin & menurun \\
semakin baik & menurut \\
mutu peruntukan &
\end{tabular} & Data SPAS \\
\hline & $\begin{array}{l}\text { 3. Kandungan pencemar } \\
\text { (polutan) }\end{array}$ & Kadar biofisik kimia & \begin{tabular}{|l} 
Menurut standar yang \\
berlaku
\end{tabular} & $\begin{array}{l}\text { Standar baku yang berlaku, misal } \\
\text { PP 20/1990 }\end{array}$ \\
\hline & $\begin{array}{l}\text { 4. Nisbah hantar sedimen } \\
\text { (SDR) }\end{array}$ & \begin{tabular}{|cr} 
SDR & Total \\
Total erosi &
\end{tabular} & $\begin{array}{l}\text { SDR }<50 \% \text { normal } \\
\text { SDR } 50-75 \% \text { tdk normal } \\
\text { SDR }>75 \% \text { rusak }\end{array}$ & $\begin{array}{l}\text { Data SPAS dan perhitungan/ } \\
\text { pengukuran erosi }\end{array}$ \\
\hline \multirow[t]{2}{*}{ C. Sosial } & 1. Kepedulian individu & $\begin{array}{l}\text { E Kegiatan positip konservasi } \\
\text { mandiri }\end{array}$ & Ada, tidak ada & Data dari instansi terkait \\
\hline & 2. Partisipasi masyarakat & $\%$ kehadiran masyarakat dalam & tinggi & pengamatan \\
\hline
\end{tabular}




\begin{tabular}{|c|c|c|c|c|}
\hline & & kegiatan bersama & $\begin{array}{ll}40-70 \% & \text { sedang } \\
<40 \% \text { rendah } & \end{array}$ & laporan instansi terkait \\
\hline & $\begin{array}{l}\text { 3. Tekanan penduduk } \\
\text { terhadap lahan }\end{array}$ & 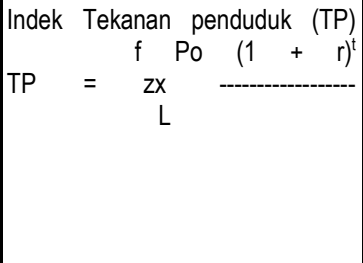 & 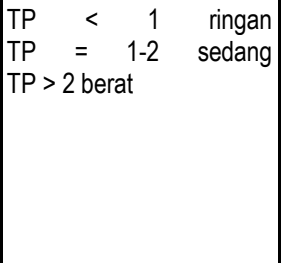 & $\begin{array}{l}t=\text { waktu dlm } 5 \text { tahun } \\
z=\text { luas lahan pertanian minimal } \\
\text { utk hidup layak/petani } \\
f=\text { proporsi petani terhadap } \\
\text { populasi penduduk DAS } \\
\text { Po = jml penduduk tahun } 0 \\
L=\text { luas lahan pertanian } \\
r=\text { Pertumbuhan penduduk/thn }\end{array}$ \\
\hline \multirow[t]{4}{*}{ D. Ekonomi } & $\begin{array}{ll}1 . & \text { Ketergantungan } \\
\text { penduduk terhadap lahan }\end{array}$ & $\begin{array}{l}\text { Kontribusi pertanian terhadap total } \\
\text { pendapatan keluarga }\end{array}$ & $\begin{array}{l}>\quad 75 \% \\
50-75 \% \\
<50 \% \text { rendah }\end{array}$ & $\begin{array}{l}\text { Dihitung KK/thn } \\
\text { Data dari instansi terkait atau } \\
\text { petani sample }\end{array}$ \\
\hline & 2. Tingkat pendapatan & Pendapatan keluarga/tahun & Garis kemiskinan BPS & $\begin{array}{l}\text { Data dari instansi terkait atau } \\
\text { petani sample }\end{array}$ \\
\hline & 3. Produktivitas lahan & Produksi/ha/thn & $\begin{array}{l}\text { Menurun, } \\
\text { meningkat }\end{array}$ & Data BPS atau petani sample \\
\hline & $\begin{array}{l}\text { 4. Jasa lingkungan (air, } \\
\text { wisata, iklim mikro, umur } \\
\text { waduk) }\end{array}$ & $\begin{array}{l}\text { Internalitas dari } \quad \text { externalitas } \\
\text { pembiayaan } \\
\text { bersama (cost sharing) }\end{array}$ & Ada, tidak ada & $\begin{array}{l}\text { Dalam bentuk pajak, retribusi } \\
\text { untuk dana lingkungan }\end{array}$ \\
\hline \multirow[t]{4}{*}{$\begin{array}{l}\text { E. } \\
\text { Kelembagaan }\end{array}$} & $\begin{array}{l}\text { 1. Pemberdayaan lembaga } \\
\text { lokal/adat }\end{array}$ & $\begin{array}{l}\text { Peranan lembaga lokal dalam } \\
\text { pengelolaan DAS }\end{array}$ & Berperan, tidak berperan & Data hasil pengamatan \\
\hline & $\begin{array}{|lr|}2 . & \text { Ketergantungan } \\
\text { masyarakat } & \text { kepada } \\
\text { pemerintah } & \\
\end{array}$ & Intervensi pemerintah & Tinggi, sedang, rendah & Data hasil pengamatan \\
\hline & 3. KI S S & konflik & Tinggi, sedang, rendah & Data hasil pengamatan \\
\hline & 4. Kegiatan usaha bersama & Jumlah unit usaha & $\begin{array}{l}\text { BErtambah, } \\
\text { tetap }\end{array}$ & Data dari instansi terkait \\
\hline
\end{tabular}

Tujuan utama dari penelitian kewenangan Dinas PSDA Provinsi adalah untuk menentukan daftar skala Jawa Tengah. Berikut ini metodologi prioritas penanganan prasarana DAS di yang akan kami terapkan di lapangan. WS Bodri Kuto yang merupakan

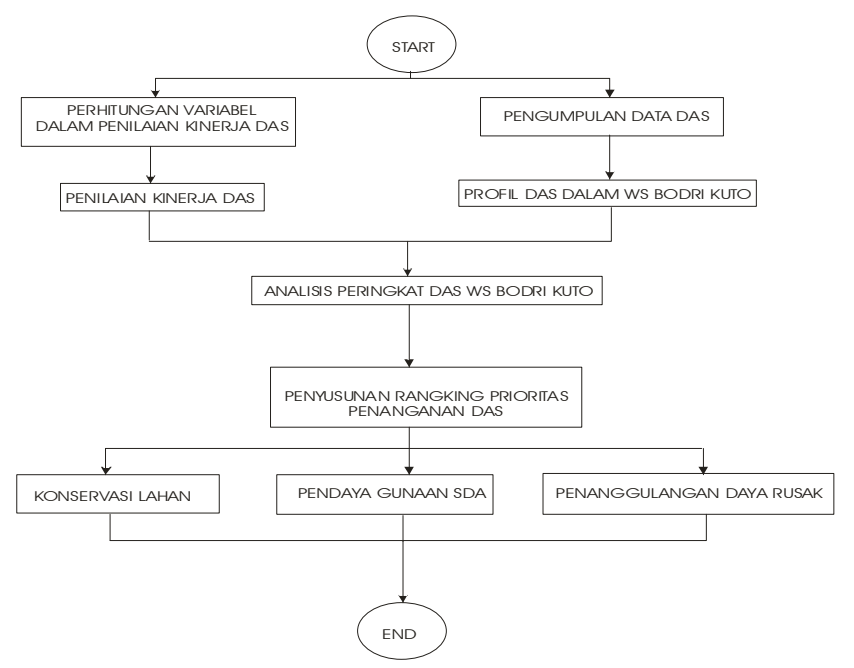

Gambar 2.1. Flow Chart Metodologi Penelitian 
Penyusunan Prioritas Perbaikan prasarana SDA Wilayah Sungai Bodri Kuto pada prinsipnya adalah pembobotan item pekerjaan / program, dengan tujuan untuk membuat rangking (tingkat) prioritas / kemendesakan program berdasarkan Matriks "Short List" jangka waktu 5 tahun ke depan. Analisis yang digunakan adalah pembobotan usulan program berdasarkan ketentuan yang telah disepakati dan ditetapkan untuk dijadikan pedoman, pegangan, dan petunjuk bagi instansi pelaksana dalam upaya merencanakan, melaksanakan, memantau dan mengevaluasi penyelenggaraan konservasi sumber daya air, pendayagunaan sumber daya air, dan pengendalian daya rusak air.

Prioritas pada prinsipnya berkenaan dengan derajat kepentingan dan keterdahuluan. Penilaian ini tidak menghapus rumusan program/proyek yang nantinya dinyatakan tidak atau kurang prioritas, karena rumusan program/proyek tersebut masih dapat dijadwalkan pada masa berikutnya selaras dengan peningkatan kemampuan pembiayaan. Program/proyek yang termasuk kategori prioritas juga dapat dijadwalkan pada tahun ke 3,4 atau 5 apabila masih harus didahului penyiapan beberapa prasyarat seperti DED, pembebasan lahan, atau aspek institusional, dsb.

Kegiatan prioritisasi merupakan suatu upaya untuk menilai serangkaian usulan program/proyek, sehingga usulan program/proyek yang diusulkan dapat sesuai dengan arahan yang telah disusun. Dengan demikian tujuannya adalah:

- Membantu perencanaan dalam menganalisis usulan-usulan program/ proyek secara efektif dan efisien

- Untuk menguji alternatif-alternatif usulan program/proyek yang dipertimbangkan dengan serangkaian tujuan dan sasaran

\section{DATA DAN ANALISIS}

Data - Data penting yang
dipergunakan dalam menganalisis
Rangking Prioritas WS Bodri Kuto dapat
diuraikan sebagai berikut.

\section{Penggunaan Lahan}

\begin{tabular}{|c|c|c|c|c|}
\hline KRITERIA & INDIKATOR & PARAMETER & STANDAREVALUASI & KETERANGAN \\
\hline \multirow{15}{*}{$\begin{array}{l}\text { A. Penggunaan } \\
\text { Lahan }\end{array}$} & 1. Penutupan oleh vegetasi & LVP & IPL>75\% baik & IPL=indek penutupan lahan \\
\hline & & $\mid P L=\ldots \ldots \times 100 \%$ & $\mid P L=30-75 \%$ sedang & LVP = luas lahan bervegetasi permanen \\
\hline & & LuasDAS & IPL $<30 \%$ jelek & Informasi dari peta penutupan lahan \\
\hline & & & & atau land use \\
\hline & 2. Kesesuaian Penggunaan & LPS & $K P L>75 \%$ baik & LPS = luas penggunaan lahan yang sesua \\
\hline & tahan (KPL) & & & \\
\hline & & $K P L==\times 100 \%$ & $\mathrm{KPL}=40 \cdot-75 \%$ sedang & Rujukan kesesuaian penggunaan lahan \\
\hline & & & & adalah RTRW/K dan atau pola RLKT \\
\hline & & Luas DAS & KPL $<40 \%$ jelek & \\
\hline & 3. Potensi Erosi & luas pot.erosi & prosentase $\leq 0,10$ baik & Dokumen Pola Peng. WS Bodri Kuto 2008 \\
\hline & & $P E=\cdots$ & prosentase $=0,10-0,50$ sedang & \\
\hline & & Eluas DAS & prosentase $\geq 0,50$ jelek & \\
\hline & 4. Potensi kelongsoran & luas pot.longsor & prosentase $\leq 0,10$ baik & Dokumen Pola Peng. WS Bodri Kuto 2008 \\
\hline & & $P L=\ldots \ldots$ & prosentase $=0,10-0,50$ sedang & \\
\hline & & Eluas DAS & prosentase $>0,50$ jelek & \\
\hline
\end{tabular}

Keterangan :

Standard evaluasi yang dihasilkan dari analisis / perhitungan, selanjutnya dijadikan bobot dengan ketentuan :

Kondisi Baik = dikalikan faktor pengali yang kecil, dalam hal ini adalah 1

Kondisi Sedang = dikalikan faktor pengali 2

Kondisi Jelek = dikalikan faktor pengali 3

Bila rentang standard evaluasi hanya "baik" dan "jelek", maka :

Kondisi Baik = dikalikan faktor pengali yang kecil, dalam hal ini adalah 1

Kondisi Jelek = dikalikan faktor pengali 3 


\section{Pengelolaan SDA}

\begin{tabular}{|c|c|c|c|c|}
\hline Kriteria & Indikator & Parameter & Standar Evaluasi & Keterangan \\
\hline B. Pengelolaan & \multirow[t]{6}{*}{ 1. Debit air sungai } & $Q \max$ & KRS $<75$ baik & PP 42/2008 \\
\hline \multirow[t]{12}{*}{ SDA } & & a. KRS = -.---.--- & KRS $>75$ kritis & $Q=$ debit sungai \\
\hline & & Q min & & \\
\hline & & $S d$ & CV $<10 \%$ baik & $\mathrm{CV}=$ coefisien varian \\
\hline & & b. $C V=$ & CV > $10 \%$ jelek & $S d=$ standar deviasi \\
\hline & & Q rata-rata & & KepmenHut 52/Kpts-II/2001 \\
\hline & \multirow{2}{*}{$\begin{array}{l}\text { 2. Nisbah pemanfaatan Sumber } \\
\text { Daya Air }\end{array}$} & $\mathrm{N}=$ jumlah volume vang digunakan & $N<1,5$ baik & Standard rata - rata Jateng \\
\hline & & Jumlah volume keseluruhan & $\mathrm{N}>1,5$ jelek & PP 42/2008 \\
\hline & 3. Kandungan sedimen & Kadar lumpur dalam air & $\begin{array}{l}\text { Semakin menurun semakin baik } \\
\text { menurut mutu peruntukan }\end{array}$ & DataSPAS \\
\hline & $\begin{array}{l}\text { 4. Kandungan pencemar } \\
\text { (polutan) }\end{array}$ & Kadar biofisik kimia & Menurut standar yang berlaku & $\begin{array}{l}\text { Standar baku yang berlaku, misal PP } \\
20 / 1990\end{array}$ \\
\hline & \multirow[t]{3}{*}{ 5. Nisbah hantar sedimen (SDR) } & Total sedimen & SDR $<50 \%$ normal & \multirow{3}{*}{$\begin{array}{l}\text { KepmenHut 52/Kpts- } 1 / 2001 \text { dan } \\
\text { perhitungan/ pengukuran erosi }\end{array}$} \\
\hline & & 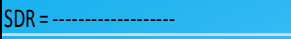 & SDR 50-75\% tdk normal & \\
\hline & & Total erosi & SDR $>75 \%$ rusak & \\
\hline
\end{tabular}

Keterangan :

Standard evaluasi yang dihasilkan dari analisis / perhitungan, selanjutnya dijadikan bobot dengan ketentuan :

Kondisi Baik = dikalikan faktor pengali yang kecil, dalam hal ini adalah 1

Kondisi Sedang = dikalikan faktor pengali 2

Kondisi Jelek = dikalikan faktor pengali 3

Bila rentang standard evaluasi hanya "baik" dan "jelek", maka :

Kondisi Baik = dikalikan faktor pengali yang kecil, dalam hal ini adalah 1

Kondisi Jelek/kritis $=$ dikalikan faktor pengali 3

\section{Kondisi Sosial}

\begin{tabular}{|c|c|c|c|c|}
\hline Kriteria & Indikator & Parameter & Standar Evaluasi & Keterangan \\
\hline \multirow[t]{9}{*}{ C. Sosial } & 1. Kepedulian individu & Ratio Tingkat Pendidikan SLTA per DAS & $\ldots$ & Data rata-rata Jateng \\
\hline & \multirow[t]{2}{*}{ 2. Jumlah penduduk dalam DAS } & jumlah tenaga kerja DAS/jumlah & $>30 \%$ tinggi & \multirow[t]{2}{*}{ PP 42/2008 } \\
\hline & & keseluruhan tenaga kerja di Wil. Sungai & $<30 \%$ rendah & \\
\hline & \multirow{6}{*}{$\begin{array}{l}\text { 3. Tekanan penduduk terhadap } \\
\text { lahan }\end{array}$} & Indek Tekanan penduduk (TP) & $\mathrm{TP}<1$ ringan & $\mathrm{t}=$ waktu $\mathrm{dlm} 5$ tahun \\
\hline & & $f P_{0}(1+r)^{t}$ & $T P=1-2$ sedang & $z=$ luas lahan pertanian minimal utk \\
\hline & & $\mathrm{TP}=2 \mathrm{x}$-.............. & TP $>2$ berat & $\begin{array}{l}\mathrm{f}=\text { proporsi petani terhadap populasi } \\
\text { penduduk DAS }\end{array}$ \\
\hline & & L & & $P_{0}=$ jml penduduk tahun 0 \\
\hline & & & & $L=$ luas lahan pertanian \\
\hline & & & & $r=$ Pertumbuhan penduduk/thn \\
\hline
\end{tabular}

Keterangan :

Untuk kondisi sosial, pembobotan menggunakan aturan yang berkebalikan dengan kondisi penggunaan lahan dan kondisi pengelolaan SDA.

Kondisi Baik/ringan = dikalikan faktor pengali yang besar, dalam hal ini adalah 3

Kondisi Sedang = dikalikan faktor pengali 2

Kondisi Jelek/berat = dikalikan faktor pengali 1

Bila rentang standard evaluasi hanya "baik" dan "jelek", maka :

Kondisi Baik/Tinggi = dikalikan faktor pengali yang besar, dalam hal ini adalah 3

Kondisi Jelek/rendah $=$ dikalikan faktor pengali 1 


\section{Kondisi Ekonomi}

\begin{tabular}{|c|c|c|c|c|}
\hline Kriteria & Indikator & Parameter & Standar Evaluasi & Keterangan \\
\hline \multirow{6}{*}{ D. Ekonomi } & \multirow{3}{*}{$\begin{array}{l}\text { 1. Ketergantungan penduduk } \\
\text { terhadap lahan beririgasi }\end{array}$} & \multirow[t]{3}{*}{ Luas lahan beririgasi dalam DAS } & $>10000 \mathrm{Ha}$ tinggi & PP 20/2006 tentang irigasi \\
\hline & & & $3000-10000$ Ha sedang & PP 42/2008 tentang PSDA \\
\hline & & & $<3000 \mathrm{Ha}$ rendah & \\
\hline & 2. Produktivitas lahan & Produksi/ha/thn & besar,sedang,kecil & Data BPS atau petani sample \\
\hline & 3. Nilai produksi terkait SDA & Pendapatan keluarga/tahun & Garis kemiskinan BPS & $\begin{array}{l}\text { Data dari instansi terkait atau petani } \\
\text { sample }\end{array}$ \\
\hline & $\begin{array}{l}\text { 4. Jasa lingkungan (wisata,PLTA, } \\
\text { mikro hidro, pengelolaan } \\
\text { waduk) }\end{array}$ & $\begin{array}{l}\text { Internalitas dari externalitas pembiayaan } \\
\text { pengelolaan bersama (cost sharing) }\end{array}$ & Ada, tidak ada & $\begin{array}{l}\text { Dalam bentuk pajak, retribusi untuk } \\
\text { dana lingkungan }\end{array}$ \\
\hline
\end{tabular}

Keterangan :

Kondisi tinggi

Kondisi sedang

$=$ dikalikan faktor pengali yang besar, dalam hal ini adalah 3

$=$ dikalikan faktor pengali yang lebih kecil, dalam hal ini adalah 2

Kondisi rendah

= dikalikan faktor pengali yang kecil, dalam hal ini adalah 1

Bila rentang standard evaluasi hanya "baik" dan "jelek", maka :

Kondisi Baik/ada = dikalikan faktor pengali yang kecil, dalam hal ini adalah 3

Kondisi Jelek/tdk ada = dikalikan faktor pengali yang kecil, dalam hal ini adalah 1

\section{Kondisi Peran Serta Masyarakat dalam Pengelolaan DAS}

\begin{tabular}{|c|l|l|l|l|}
\hline \multicolumn{1}{|c|}{ Kriteria } & \multicolumn{1}{|c|}{ Indikator } & \multicolumn{1}{c|}{ Standar Evaluasi } & \multicolumn{1}{c|}{ Keterangan } \\
\hline \multirow{3}{*}{$\begin{array}{l}\text { E. Peran Serta } \\
\text { masyarakat }\end{array}$} & $\begin{array}{l}\text { 1. Lembaga pemberdayaan } \\
\text { Masyarakat }\end{array}$ & $\begin{array}{l}\text { Peranan lembaga lokal dalam pengelolaan } \\
\text { DAS }\end{array}$ & Berperan, tidak berperan & Data hasil pengamatan \\
\cline { 2 - 5 } & 2. Partisipasi Masyarakat & Intervensi pemerintah & Ada, tidak ada & Data hasil pengamatan \\
\cline { 2 - 6 } & 3. program pemberdayaan & konflik & Ada, tidak ada & Data hasil pengamatan \\
\cline { 2 - 5 } & $\begin{array}{l}\text { 4. Kegiatan usaha bersama } \\
\text { terkaitSDA }\end{array}$ & Jumlah unit usaha & Bertambah, berkurang, tetap & Data dari instansi terkait3 tahun terakhir \\
\hline
\end{tabular}

Keterangan :

Untuk kondisi sosial, pembobotan menggunakan aturan yang berkebalikan dengan kondisi penggunaan lahan dan kondisi pengelolaan SDA.

Kondisi Baik/ringan = dikalikan faktor pengali yang besar, dalam hal ini adalah 3

Kondisi Sedang = dikalikan faktor pengali 2

Kondisi Jelek/berat = dikalikan faktor pengali 1

Bila rentang standard evaluasi hanya "baik" dan "jelek", maka :

Kondisi Baik/ada = dikalikan faktor pengali yang besar, dalam hal ini adalah 3

Kondisi Jelek/tdk ada $=$ dikalikan faktor pengali 1

Rekapitulasi identifikasi (dalam bentuk bobot) Wilayah Sungai Bodri Kuto disajikan dalam Tabel berikut. 


\begin{tabular}{|c|c|c|c|c|c|c|c|c|c|c|c|}
\hline & & IDENTI & TIFIKASI / PEI & ЕМВОВОТА & $\begin{array}{l}\text { TABEL } \\
\text { AN WILAYA }\end{array}$ & H SUNGAI B & BODRI KUTO & & & & \\
\hline PARAMETER / VARIABEL & KUTO & DAMAR & \begin{tabular}{|l|l} 
BULANAN & B \\
\end{tabular} & BLUKAR & BODRI & BUNTU & KENDAL & BLORONG & WARIDIN & All & PLUMBON \\
\hline \begin{tabular}{|l|} 
A. Penggunaan Lahan \\
\end{tabular} & & & & & & & & & & & \\
\hline 1 Penutupan oleh vegetasi & 2 & 3 & 3 & 3 & 2 & 3 & 3 & 2 & 3 & 2 & 2 \\
\hline $\begin{array}{l}\begin{array}{l}\text { Kesesuaian Penggunaan } \\
2 \\
\text { Lahan (KPL) }\end{array} \\
\end{array}$ & & 2 & & 2 & 1 & 1 & 3 & 2 & 1 & & 3 \\
\hline $\begin{array}{l}\text { Potensi Erosi (erosi sedang } \\
3 \mathrm{~s} / \mathrm{d} \text { tinggi) }\end{array}$ & 2 & 2 & 1 & 3 & 3 & 1 & 2 & 2 & 1 & & \\
\hline $4 \mid \begin{array}{l}\text { Potensi Longsor (longsor } \\
\text { menengah ke tinggi) }\end{array}$ & 2 & 2 & 1 & 2 & 3 & 1 & 1 & 2 & 1 & & \\
\hline B. Pengelolaan SDA & & & & & & & & & & & \\
\hline 1 Debit air sungai (KRS) & 3 & 3 & 3 & 3 & 3 & 3 & 3 & 3 & 3 & 3 & 3 \\
\hline $\begin{array}{l}\begin{array}{l}\text { Nisbah pemanfaatan } \\
2 \text { Sumber Daya Air (N) }\end{array} \\
\end{array}$ & & & 3 & & & & & & 3 & & \\
\hline 3 Kandungan sedimen & 正 & a & 0 & 0 & 0 & 0 & 0 & 0 & 0 & 0 & 0 \\
\hline \begin{tabular}{|l|l|} 
Kandungan pencemar \\
(polutan)
\end{tabular} & 3 & 1 & 2 & 1 & 1 & 3 & 3 & 3 & 3 & 2 & 2 \\
\hline $\begin{array}{l}\text { 4 Nisbah hantar sedimen } \\
\text { (SDR) }\end{array}$ & 1 & 3 & 3 & 2 & 1 & 3 & 3 & 1 & 3 & 2 & \\
\hline \begin{tabular}{|l|} 
C. Sosial \\
\end{tabular} & & & & & & & & & & & \\
\hline \begin{tabular}{|l|l|} 
& Kepedulian individu (Rasio \\
1 & SLTA/DAS) \\
\end{tabular} & 0 & 0 & 0 & 0 & 0 & 0 & 0 & 0 & 0 & 0 & 0 \\
\hline $\begin{array}{l}\text { Jumlah tenaga kerja dalam } \\
2 \text { DAS }\end{array}$ & & 1 & 1 & & 0 & 0 & 0 & 0 & 0 & & 0 \\
\hline $\begin{array}{l}\text { Tekanan penduduk } \\
3 \text { terhadap lahan (TP) } \\
\end{array}$ & & 3 & 3 . & & 1 & 1. & 3. & 1 & 3 & & \\
\hline D. Ekonomi & & & & & & & & & & & \\
\hline $\begin{array}{l}\begin{array}{l}\text { Ketergantungan penduduk } \\
\text { terhadap lahan beririgasi } \\
\text { (Luas Lahan beririgasi) }\end{array} \\
\end{array}$ & I & 4 & 1 & & 3 & 1 & 1 & 2 & 1 & 1 & \\
\hline $2 \begin{array}{l}\text { Produktivitas lahan } \\
\text { (produksi DAS/WS) }\end{array}$ & 4 & 4 & 1 & & 3 & 1 & 1 & 1 & 1 & & \\
\hline $\begin{array}{l}\text { Nilai produksi terkait SDA } \\
\text { (pendapatan KK/Tahun) }\end{array}$ & 2 & & 1 & & 3 & 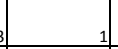 & 1 & 1 & 1 & & \\
\hline 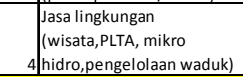 & 0 & 0 & 0 & 0 & 0 & 0 & 0 & 0 & 0 & 0 & 0 \\
\hline E. Peran Serta Masyarakat & & & & & & & & & & & \\
\hline $\begin{array}{l}\text { Lembaga pemberdayaan } \\
1 \text { Masyarakat }\end{array}$ & 0 & 0 & 0 & 0 & 0 & of & 0 & 0 & 0 & 0 & 0 \\
\hline \begin{tabular}{|l|l|}
2 & Partisipasi Masyarakat
\end{tabular} & 0 & 0 & 0 & 0 & 0 & 0 & 0 & 0 & 0 & 0 & 0 \\
\hline 3 program pemberdayaan & 3 & 1 & 1 & 1 & 3 & 1 & 3 & 1 & 1 & 1 & 1 \\
\hline $\begin{array}{l}\text { Kegiatan usaha bersama } \\
\text { terkait SDA }\end{array}$ & 3 & 1 & 1 & 2 & 3 & 1 & 1 & 2 & 1 & & 1 \\
\hline
\end{tabular}

Struktur Hierarchy AHP Expert Choice yang digunakan dalam menganalisis rangking prioritas perbaikan prasarana WS Bodri Kuto adalah sebagai berikut :

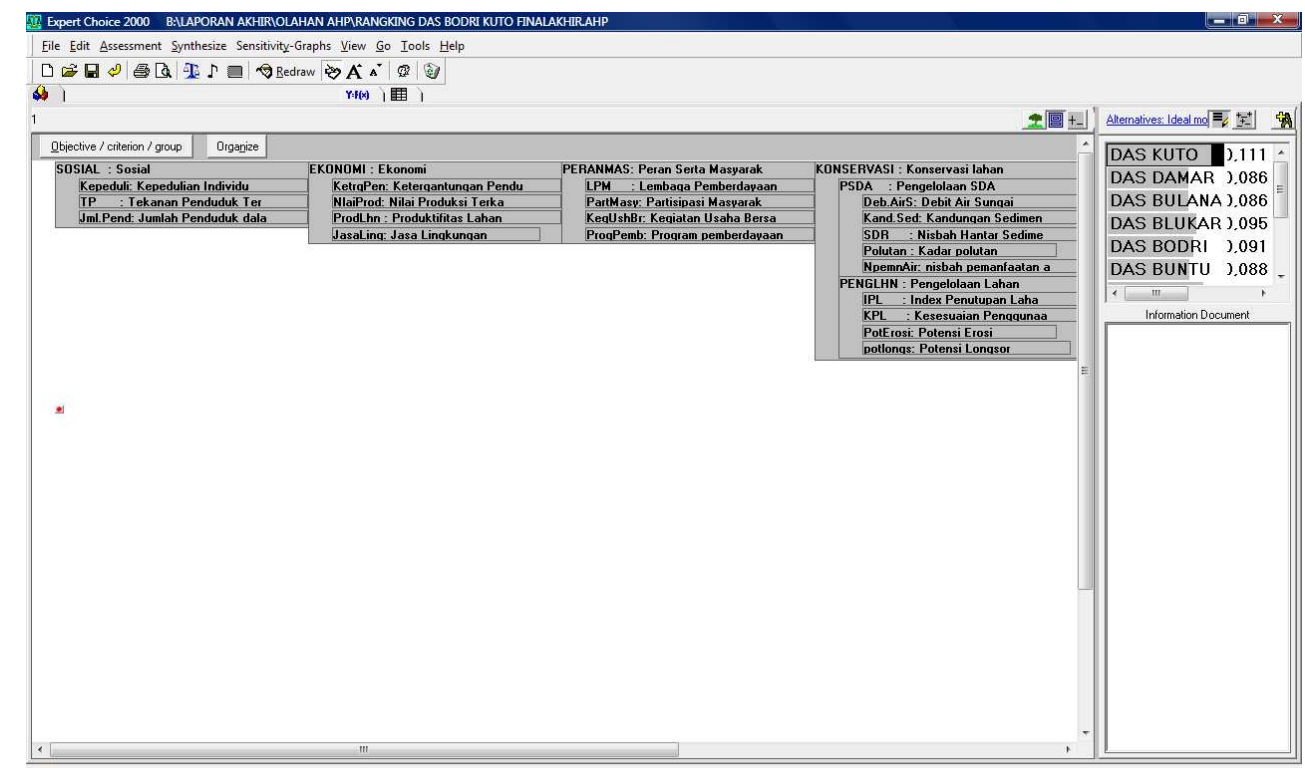




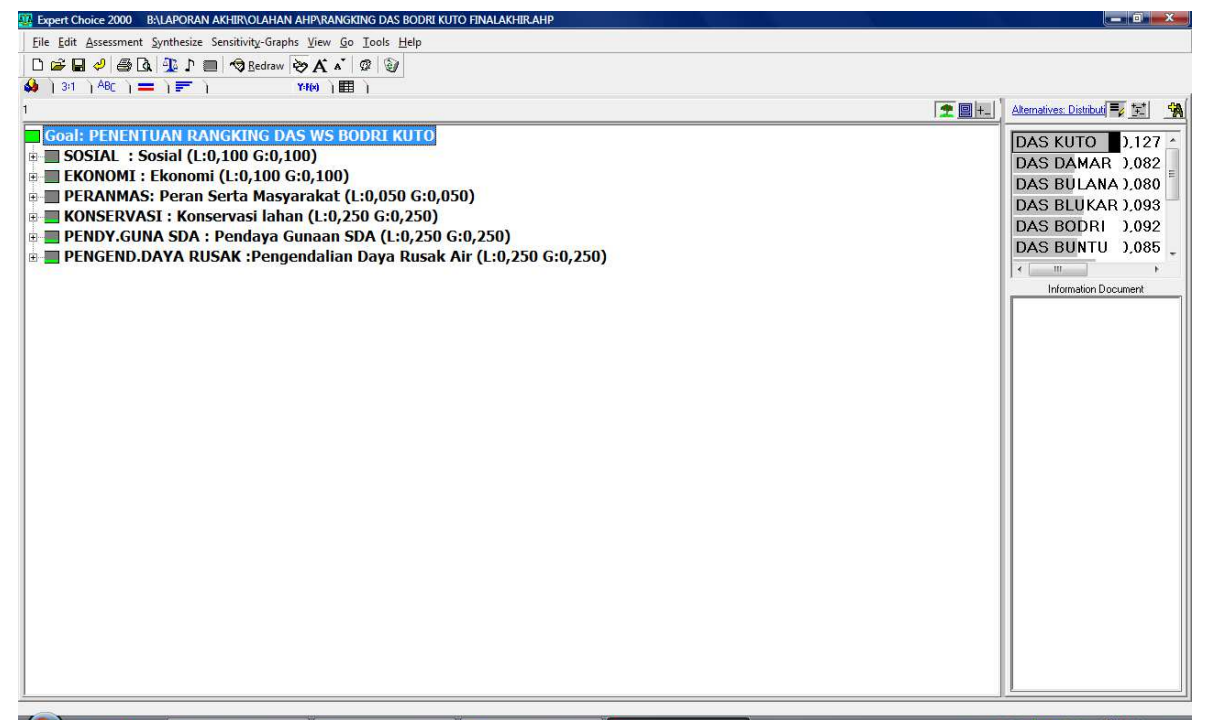

Keterangan :

Parameter yang dijadikan pertimbangan dalam menentukan rangking prioritas perbaikan prasarana WS BODRI KUTO adalah :

Kondisi Sosial

Kondisi Ekonomi

: bobot $10 \%$

: bobot $10 \%$

Peranserta Masyarakat : bobot $5 \%$

Konservasi : bobot $25 \%$

Pendayagunaan SDA : bobot $25 \%$

Pengendalian Daya Rusak : bobot 25\%

\section{Hasil Analisis :}

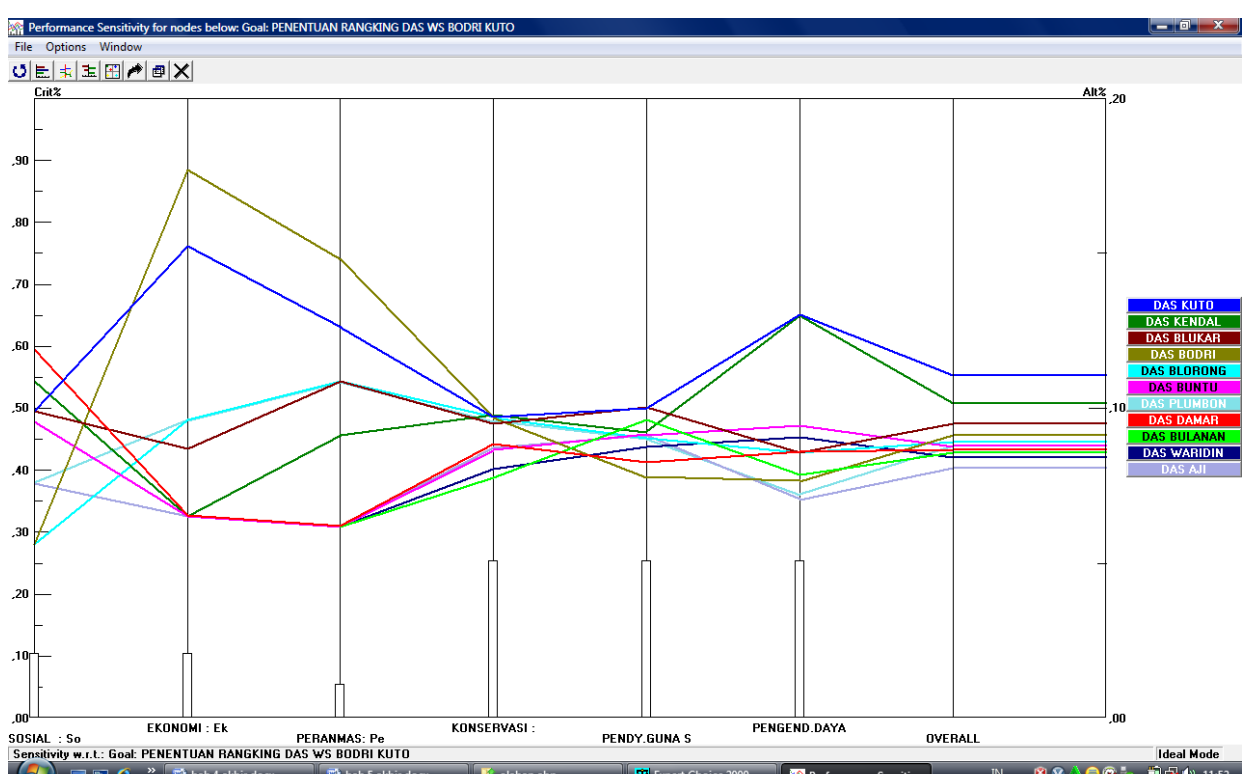




\section{KESIMPULAN DAN SARAN \\ Kesimpulan}

Hasil studi Analisis Prioritas

Penanganan Perbaikan Prasarana SDA

WS Bodri Kuto dengan AHP Expert Choice menghasilkan rangking prioritas DAS yang perlu ditangani sebagai berikut :
1. DAS Kuto
2. DAS Damar
3. DAS Bulanan
4. DAS Blukar
5. DAS Bodri
6. DAS Buntu
7. DAS Kendal
8. DAS Blorong
9. DAS Waridin
10. DAS Aji
11. DAS Plumbon

\section{Saran}

Dari hasil Daftar Skala Prioritas DAS di Wilayah Sungai (WS) Bodri Kuto seperti tersebut diatas, agaknya diperlukan penelitian lanjutan mengenai Detail Program Penanganan Pembangunan Prasarana yang perlu disusun dalam tiap DAS, yang tentunya juga dalam bentuk matriks skala prioritas pula.

\section{DAFTAR PUSTAKA}

Arsyad S. Konservasi Tanah dan Air, IPB, Bogor, 1989.

Barus dan Suwardjo. 1977. Hubungan antara Sifat-sifat Hujan dengan Erosi, Kongres Nasional IImu Tanah II, Jogyakarta.

Chow, V.T., Hand Book of Applied Hydrologi, Mc. Graw Hill, Books Company, New York, 1964

Hudson, N.W., Soil Coservation and Management in the Humid Tropics, Chichester, John Wiley \& Sons Ltd., 1977.

Indra Karya PT., Design Review of Opak Serang Irrigation Rehabilitation Project, Yogyakarta, 1990

Kohnke, H. and A.R. Bertrand, Soil Conservation, New York, McGraw-Hill, 1959
Puslitbang Pengairan PU, Bendungan Besar di Indonesia, Badan Penelitian dan Pengembangan Pekerjaan Umum Departemen Pekerjaan Umum, Jakarta, 1995.

Sarief, E.S. Konservasi Tanah dan Air, Cet. III, Bandung : CV. Pustaka Buana, 1985.

Seta, A.K. Konservasi Sumber daya Tanah dan Air, Cet. II Jakarta : Kalam Mulia, Agustus 1991.

Sheuerlein, H., Sedimentation of reservoirs Methodes of Prevention, Techniques of Rehabilitation, First Iranian Symposium on Dam Engineering, p. 56, Tehran (1987).

Strand, R. I. Sedimentation - Design of Small Dams, $2^{\text {nd }}$ ed. New Delhi : Oxford \& IBH Publishing CO, 1979.

Strand, R. I., Design of Small Dams, U.S. Bureau of Reclamation, Oxford \& IBH Publishing Co., New Delhi, 1974.

Suripin, Konservasi Tanah dan Air, Magister Teknik Sipil Universitas Diponegoro, Semarang, 2000.

Suryadi P.A, Pendahuluan Teori Kemungkinan dan Statistika, Departemen Matematika ITB, Bandung, 1980.

Wischmeier, W.H. and D.D. Smith, Predicting Rainfall Erosion Losses from Cropland East of the Rocky Mountains, USDA, Agriculture Handbook No. 282, 1965. 